\title{
Author Correction: Major restructuring of marine plankton assemblages under global warming
}

\author{
Fabio Benedetti (1), Meike Vogt, Urs Hofmann Elizondo (D), Damiano Righetti, Niklaus E. Zimmermann (1) \& \\ Nicolas Gruber (i)
}

Correction to: Nature Communications https://doi.org/10.1038/s41467-021-25385-x, published online 1 September 2021.

In the Acknowledgements section, the funding source 'F.B. received support from ETH Zürich and from the European Union's Horizon 2020 research and innovation program under grant agreement no. SEP-210591007' should have read 'F.B. received support from ETH Zürich. This project has received funding from the European Union's Horizon 2020 research and innovation programme under grant agreement no. 862923. This output reflects only the author's view, and the European Union cannot be held responsible for any use that may be made of the information contained therein.'. The original article has been corrected.

Published online: 26 October 2021

\footnotetext{
(c) (i) Open Access This article is licensed under a Creative Commons Attribution 4.0 International License, which permits use, sharing, adaptation, distribution and reproduction in any medium or format, as long as you give appropriate credit to the original author(s) and the source, provide a link to the Creative Commons license, and indicate if changes were made. The images or other third party material in this article are included in the article's Creative Commons license, unless indicated otherwise in a credit line to the material. If material is not included in the article's Creative Commons license and your intended use is not permitted by statutory regulation or exceeds the permitted use, you will need to obtain permission directly from the copyright holder. To view a copy of this license, visit http://creativecommons.org/licenses/by/4.0/.
}

() The Author(s) 2021 